九州大学学術情報リポジトリ

Kyushu University Institutional Repository

\title{
The Impact of Country Reputation on Export Quality of Agricultural Products
}

HUAI, Dinghui

College of Economics and Management, Nanjing Agricultural University

MAEDA, Koshi

Laboratory of Quantitative Food Economic Analysis, Division of Agricultural and Resource

Economics, Department of Agricultural and Resource Economics, Faculty of Agriculture, Kyushu University

WANG, Xue jun

College of Economics and Management, Nanjing Agricultural University

https://doi.org/10.5109/2558912

出版情報: 九州大学大学院農学研究院紀要. 65 (1)，pp.193-199，2020-02. Faculty of Agriculture， Kyushu University

バージョン :

権利関係 : 


\title{
The Impact of Country Reputation on Export Quality of Agricultural Products
}

\author{
Dinghui HUAI ${ }^{1}$, Koshi MAEDA and Xuejun WANG ${ }^{1 *}$ \\ Laboratory of Quantitative Food Economic Analysis, Division of Agricultural and Resource Economics, \\ Department of Agricultural and Resource Economics, Faculty of Agriculture, \\ Kyushu University, Fukuoka 819-0395, Japan \\ (Received October 31, 2019 and accepted November 14, 2019)
}

\begin{abstract}
Country reputation is considered to be an important factor that impacts export quality. Most literature focuses on theoretical frameworks of country reputation, while few studies provide empirical support for theoretical findings. Using the data of 324,183 observations representing 131 countries exporting153 agricultural products from 1996 to 2011, this paper investigates the extent to which country reputation matters for export quality. The results strongly suggest that country reputation has a positive and significant impact on export quality and the effect is more pronounced for highly differentiated products. These results are robust to various checks. Moreover, the heterogeneous effects of country reputation on quality upgrading are identified when the sample is split based on different classifications.
\end{abstract}

Key words: Agricultural goods, Asymmetric information, Country reputation, Export quality

\section{INTRODUCTION}

In recent years, the international trade of agricultural products has seen the growing importance of quality as a fundamental feature of products (Minten $e t$ al., 2013; Olper et al., 2014; Curzi et al., 2015). Consumers have become increasingly concerned about quality because of their rising incomes. Especially in developed countries, consumers have become more demanding, more critical, and more fragmented in their product selection. Competition in the international agricultural market has switched from price-based to quality-based. Improving product quality has become an important driver of the market competitiveness in the international market. Among the factors that determine export quality, country reputation has received considerable attention in recent years. Asymmetric information is common in the international market since buyers in foreign markets cannot verify the quality of the imported products that they purchase (Akerlof, 1970). Agricultural products have a more serious problem of asymmetric information since they have the characteristics of both experience goods and credence goods. Buyers find it hard to observe their quality in advance and may not be able to ascertain it even after consumption. Under these circumstances, the belief in the average quality of the exporter (which is affected by country reputation) would affect a buyer's purchasing behaviors. After Melitz (2003) developed the dynamic industry model with heterogeneous firms, the issue of country reputation began to capture the attention of scholars. Actually, research on country reputation already had a long history in the international trade field. Some studies in

${ }^{1}$ College of Economics and Management, Nanjing Agricultural University, Nanjing 210095, China

* Corresponding author (E-mail: wangxj@njau.edu.cn) marketing study "the country of origin" from a consumer perspective. Research into the country of origin has focused on various issues such as brand effects, product quality, price, consumer perceptions, technology sophistication, product features and country images to measure consumer perceptions and purchasing behaviors (Bilkey and Nes, 1982; Hamzaoui and Merunka, 2006; Mohd et al., 2007; Khan and Bamber, 2008). Studies find that consumers form their attitudes toward a foreign-made product based on the country-of-origin image (Erdem et al., 2006; Clarke et al., 2000; Chattalas et al., 2008; Phillips et al., 2013). Some studies also focus on the impact of collective reputation on firms' export behaviors. The collective reputation reflects the average past behavior of members of the group and each member's incentives are affected by the group's reputation (Tirole, 1996). Collective reputation is believed to be an effective means of identifying a firm's quality choice (McQuade et al., 2016).

The idea of collective reputation is subsequently introduced into the field of international trade and forms the concept of country reputation. Country reputation determines the quality that foreign buyers expect before they learn any information specific to a product (Chisik, 2003; Cagé and Rouzet, 2015). Most studies focus on theoretical frameworks of country reputation and have made many substantial contributions. Dasgupta and Mondria (2018) develop a dynamic, two-country model and find that for home exporters, country reputation would affect their costs of signaling quality in the foreign market and the opportunity costs of exporting due to buyers' choice of suboptimal quality in the home market, thus affecting their export quality choice. Chisik (2003) find that country reputation determines not only the average quality of a country's exports but also the type of products in which a country specializes. This reputational comparative advantage may outweigh any techno- 
logical comparative advantage. Cagé and Rouzet (2015) analyze the impact of country reputation on export behavior and find that countries with bad quality reputations can be locked into exporting low-quality, low-cost goods.

Theoretical research is so far ahead of empirical studies in the field of country reputation, and few studies provide empirical support for these theoretical findings. Considering the issue of asymmetric information in international agricultural trade, we use agricultural trade data to test whether the role of country reputation on export quality exists and how country reputation affects exporters' quality choice for exported agricultural products. We extend the method of Deng and Liu (2018) and use the data of 324,183 observations representing 131 countries exporting 153 agricultural products from 1996-2011 to study the relationship between county reputation and the export quality of agricultural products. For the model estimation, our main variables of interest, quality and country reputation, are not directly observable; thus, we use the method and data from Feenstra and Romalis (2014) to estimate them. Moreover, to further verify the robustness of our main results, we use different definitions of country reputation, alternative proxy variables for export quality and remove the outliers to re-estimate our equation. We also generate some subsamples to examine the heterogeneous effects of county reputation on export quality.

The rest of this paper is organized as follows. The next section presents the empirical strategy and our data set. Section 3 discusses the results, and Section 4 offers concluding remarks.

\section{EMPIRICAL MODEL, VARIABLES AND DATA}

In this section, we specify our empirical model and describe the data and measurements that are used to estimate the key variables.

\section{Empirical model}

We adopt the estimation strategies that were suggested by Deng and Liu (2018) and refer to Faruq (2011) and Nunn (2007) when considering which factors influence export quality. Compared with the cross-sectional data that were used by Deng and Liu (2018), the panel data in this paper can improve the efficiency of the econometric estimates and can control the impact of omitted variables (Hsiao, 2007).

The exact specification of the empirical model is as follows:

$$
\begin{aligned}
& \operatorname{lnEXPQ_{ikt}}=\alpha_{0}+\beta_{1} \ln C R_{i t}+\beta_{2} \operatorname{lnCR}_{i t}^{*} \text { qualitysd }_{k t} \\
& +\beta_{3} \ln G D P P C_{i t}+\beta_{4} \ln R D_{i t}+\beta_{5} \ln F D I_{i t} \\
& +\alpha_{t}+\alpha_{k}+\alpha_{k t}+\varepsilon_{i k t}
\end{aligned}
$$

where the subscripts $i, k$, and $t$ respectively stand for the country, product and year. $E X P Q_{i k t}$ is country $i$ 's export quality level for product $k$ in year $t$. $C R_{i t}$ denotes country $i$ 's reputation, and qualitys $d_{k t}$ denotes the standard deviation of the quality of product $k$ in year $t$.
$G D P P C_{i t}, R D_{i t}$, and $F D I_{i t}$ respectively refer to the GDP per capita, research and development and foreign direct investment of country $i$. We include these three variables as control variables for the following reasons. As determinants of export quality, studies suggest that richer countries are more likely to export better quality products (Flam and Helpman, 1987; Schott, 2004; Hummels and Klenow, 2005). Innovations in technologically advanced countries can promote the upgrading of export quality (Flam and Helpman, 1987; Faruq, 2010). Research and Development (R\&D) plays a critical role in the innovation process and is a key factor in developing new competitive advantages. Furthermore, the majority of the most competitive economies have registered the highest R\&D expenditures as a percentage of GDP (Heneric et al., 2006). Many studies have used R\&D spending to analyze the relationship between technological innovation and export quality (Aw et al., 2008; Sandu and Ciocanel, 2014). Some studies have also examined the effect of foreign direct investment (FDI) on the quality of exports (Damijan et al., 2003; Zhang, 2005; Iwamoto and Nabeshima, 2012). There is a widely shared view that FDI helps transfer technology from abroad to upgrade products and provides training for the local workforce, which enhances their ability to improve their product quality.

Finally, $\alpha_{t}, \alpha_{k}$, and $\alpha_{k t}$ respectively denote the year fixed effects, product fixed effects and product-year fixed effects. Note that the time fixed effects capture the time-varying characteristics of the exporting country, global macroeconomic conditions and factors affecting the trade costs of the exporting country. Furthermore, the product fixed effects capture the systematic differences in the production and R\&D environments across products, while the product-year fixed effects control for the time-varying characteristics of product characteristics, such as production levels. $\varepsilon_{\text {ikt }}$ is the error term that includes all unobserved factors that may affect product quality.

\section{Variables and data}

The quality of exported products, $E X P Q_{i k t}$, cannot be directly observed and needs to be estimated. Using unit values (average trade prices for each product category) to measure product quality is common in the international trade literature. The conjecture is that higher unit values reflect a higher willingness to pay for a given product (Curzi and Pacca, 2015). However, unit values are at best a noisy proxy for export quality since they can also be driven by other factors (Aiginger, 1997). The strategies that have been developed for quality estimation in recent years (including Khandelwal, 2010; Khandelwal et al., 2013; Hallak and Schott, 2011) typically model demand using explicit microeconomic foundations and indirectly infer product quality from observed prices and demands. However, these methodologies do not allow for the calculation of a set of quality estimates with large country and time coverages due to their significant data requirements (Henn et al., 2015). Fortunately, Feenstra and Romalis (2014) identify the 
quality and quality-adjusted prices for a wide range of traded goods over many countries and years and construct the CEKS price indexes for the imports and exports of each country ${ }^{1}$. We adopt their data and use the difference between the price index and qualityadjusted price index as the quality measure. The data are available at the website of Feenstra and Romalis ${ }^{2}$.

Another variable of interest, country reputation, $C R_{i t}$, can be presented both in a narrow and broad sense. The former is often used in empirical studies where country reputation is expressed by the previous export quality level of a country. In this article, country reputation is represented by the export quality index. It is the industry-level index of export quality, and it can be obtained from Feenstra and Romalis (2014). To reduce the potential for an endogeneity problem, the export quality index is lagged by two years. qualitys $d_{k t}$ is the standard deviation of export quality at the product-year level. Its interaction term with country reputation $\left(\operatorname{lnCR}{ }_{i t}{ }^{*}\right.$ qualitysd $d_{k t}$ ) measures the heterogeneous effect of country reputation when considering product differentiation. The greater the standard deviation is, the higher the product differentiation.

$G D P P C_{i t}, R D_{i t}$, and $F D I_{i t}$ respectively denote country $i$ 's per capita income, research and development, and foreign direct investment. Data on GDP per capita (measured in constant 2010 U.S. dollars), R\&D (as a percentage of GDP) and FDI inflows (as a percentage of GDP) are taken from the World Development Indicators, which are published annually by the World Bank.

Feenstra and Romalis (2014) provide data at the SITC 4-digit level. To distinguish agricultural products and non-agricultural products, we match the SITC4 codes with HS2007 at the 2-digit level of the Harmonized System codes (HS2) and only keep the data on agricultural products ${ }^{3}$. Finally, our data set covers 324,183 observations representing 131 countries exporting 153 agricultural products (at the SITC4-digit level, Revision 2) over the period from 1996-2011. Table1 pre-

Table 1. Summary statistics

\begin{tabular}{lllll}
\hline VARIABLES & Mean & Std. Dev. & Min & Max \\
\hline EXPQ & 0.24 & 1.28 & -11.30 & 190.43 \\
CR & 1.40 & 3.18 & 0.06 & 79.35 \\
quality $_{\text {sd }}$ & 0.42 & 0.66 & 0.00 & 63.89 \\
GDPPC & 20540.75 & 19654.01 & 223.66 & 111968.40 \\
R\&D & 1.08 & 0.93 & 0.00 & 4.43 \\
FDI & 5.79 & 16.13 & -58.32 & 451.72 \\
\hline
\end{tabular}

Notes: EXPQ stands for export quality level; CR stands for country reputation; quality sd $_{\text {sd }}$ is the standard deviation of quality, GDPPC stands for General Domestic Products Per Capita; R\&D stands for research and development; FDI stands for foreign direct investment. The units for GDPPC, R\&D and FDI are US $\$, \%$ and $\%$, respectively. sents the descriptive statistics of the variables that are used in this paper. The table shows that the export quality index of different product categories varies from the smallest export quality index of -11.30 to the largest of 190.43, which means that there is a large difference in quality across different export products.

\section{RESULTS}

\section{Main results}

The main results that are obtained from estimating equation (1) using the OLS are presented in Table 2. As reported in Column 1, there is a significant positive coefficient for $\ln C R_{i t}$, which suggests that the improvement of country reputation is associated with an increase in export quality. The coefficient of the interaction between $\ln C R_{i t}$ and qualitysd $d_{k t}$ is significant and positive, which means that the positive impact of country reputation on export quality is more pronounced for highly differentiated products and suggests that lowreputation countries may be dragged down by the low quality reputation of their highly differentiated products. Moreover, the positive coefficient of $\ln G D P P C_{i t}$ shows that countries with higher GDP per capita export higher quality products, which is consistent with the previous idea that richer countries are more likely to export higher quality goods. The coefficient of $l n F D I_{i t}$ is significantly negative, which is not consistent with what we expected. This is perhaps because low-reputation countries are usually developing countries, and they have better FDI absorptive capacities. However, it is sometimes suggested that FDI may transfer technologies that are low level or inappropriate for the host country's factor proportions (Zhang, 2005); thus, the technologies do not significantly improve product quality.

The results are robust and consistent with the findings in Column 1 when fixed effects related to the year, product and year-product are included in a stepwise manner (Columns (2) - (4) of Table 2). It should be noted that when controlling for both the year and product or year-product fixed effects, the coefficient of $\ln R D_{i t}$ becomes significantly positive. This finding suggests that individuals change over time and it is necessary to control for fixed effects. All of the year, product, and year-product fixed effects will be controlled for in the subsequent regression analyses to avoid bias when unobservable year or individual effects are related to explanatory variables.

\section{Heterogeneous results}

In this section, we test the model on more heterogeneous samples to enhance the results' generalizability.

\section{Agricultural vs. Non-agricultural products}

Since agricultural products are usually experience

\footnotetext{
${ }^{1}$ GEKS price refers to the price of a country relative to the base country (United States).

2 The URL is: http:// cid.economic.Udavis.Edu/HTML/Quality_Data_Page.Html.

3 The HS2 codes that are used to classify agricultural trade are from 01 to 24 according to Annex 1of the Uruguay Round (UR) Agreement on Agriculture.
} 
Table 2. Effects of country reputation on export quality: baseline results

\begin{tabular}{|c|c|c|c|c|}
\hline Variables & $\begin{array}{l}(1) \\
\ln \mathrm{EXPQ}\end{array}$ & $\begin{array}{l}(2) \\
\ln \mathrm{EXPQ}\end{array}$ & $\begin{array}{l}(3) \\
\ln \mathrm{EXPQ}\end{array}$ & $\begin{array}{l}(4) \\
\ln \mathrm{EXPQ}\end{array}$ \\
\hline \multirow[t]{2}{*}{$\operatorname{lnCR}_{\mathrm{i}, \mathrm{t}-2}$} & $0.0399 * * *$ & $0.0419^{* * *}$ & $0.0630 * * *$ & $0.0665^{* * *}$ \\
\hline & $(0.0075)$ & $(0.0075)$ & $(0.0070)$ & $(0.0069)$ \\
\hline \multirow[t]{2}{*}{$\operatorname{lnCR}_{\mathrm{i}, \mathrm{t}-2} *$ qualitysd $\mathrm{kt}_{\mathrm{kt}}$} & $0.0502 * * *$ & $0.0495^{* * *}$ & $0.0289 * * *$ & $0.0295^{* * *}$ \\
\hline & $(0.0064)$ & $(0.0064)$ & $(0.0060)$ & $(0.0059)$ \\
\hline \multirow{2}{*}{$\operatorname{lnGDPPC}_{\mathrm{it}}$} & $0.0377 * * *$ & $0.0382^{* * *}$ & $0.0597 * * *$ & $0.0628^{* * *}$ \\
\hline & $(0.0046)$ & $(0.0047)$ & $(0.0043)$ & $(0.0043)$ \\
\hline \multirow[t]{2}{*}{$\operatorname{lnRD_{\text {it}}}$} & 0.0065 & 0.0068 & $0.0197^{* * *}$ & $0.0259^{* * *}$ \\
\hline & $(0.0054)$ & $(0.0054)$ & $(0.0050)$ & $(0.0050)$ \\
\hline \multirow[t]{2}{*}{$\operatorname{lnFDI} I_{\mathrm{it}}$} & $-0.0400 * * *$ & $-0.0375 * * *$ & $-0.0380 * * *$ & $-0.0378^{* * * *}$ \\
\hline & $(0.0033)$ & $(0.0034)$ & $(0.0031)$ & $(0.0031)$ \\
\hline \multirow[t]{2}{*}{ Constant } & $-1.3346 * * *$ & $-1.3419 * * *$ & $-1.6525 * * *$ & $-1.5759 * * *$ \\
\hline & $(0.0450)$ & $(0.0450)$ & $(0.0447)$ & $(0.0412)$ \\
\hline year FE & NO & YES & YES & - \\
\hline product FE & NO & NO & YES & - \\
\hline product-year FE & NO & NO & NO & YES \\
\hline Observations & 123,468 & 123,468 & 123,468 & 123,452 \\
\hline R-squared & 0.0042 & 0.0056 & 0.1509 & 0.2058 \\
\hline
\end{tabular}

Notes: Standard errors are in parentheses and are robust to clustering. $*$, ** and $* * *$ indicates significance at the 10,5 and 1 percent level, respectively.

Table 3. Heterogeneous effects on export quality

\begin{tabular}{|c|c|c|c|c|c|c|c|c|c|c|}
\hline \multirow{2}{*}{$\begin{array}{c}\text { Classification } \\
\text { Variables }\end{array}$} & \multicolumn{2}{|c|}{ sector } & \multicolumn{3}{|c|}{ end-use } & \multicolumn{2}{|c|}{ BEC } & \multicolumn{3}{|c|}{ export countries } \\
\hline & $\begin{array}{l}\text { (1) } \\
\text { agri }\end{array}$ & $\begin{array}{c}\text { (2) } \\
\text { non-agri }\end{array}$ & $\begin{array}{l}\text { (3) } \\
\text { intermediate }\end{array}$ & $\begin{array}{l}\text { (4) } \\
\text { consumption }\end{array}$ & $\begin{array}{c}\text { (5) } \\
\text { capital }\end{array}$ & $\begin{array}{c}\text { (6) } \\
\text { primary }\end{array}$ & $\begin{array}{c}\text { (7) } \\
\text { processed }\end{array}$ & $\begin{array}{c}\text { (8) } \\
\text { low- } \\
\text { income }\end{array}$ & $\begin{array}{c}\text { (9) } \\
\text { middle- } \\
\text { income }\end{array}$ & $\begin{array}{c}\text { (10) } \\
\text { high- } \\
\text { income }\end{array}$ \\
\hline $\operatorname{lnCR}_{\mathrm{i}, \mathrm{t}-2}$ & $\begin{array}{c}0.0665^{* * * *} \\
(0.0069)\end{array}$ & $\begin{array}{c}0.0326^{* * *} \\
(0.0017)\end{array}$ & $\begin{array}{c}0.0552 * * * \\
(0.0097)\end{array}$ & $\begin{array}{c}0.0719 * * * \\
(0.0082)\end{array}$ & $\begin{array}{l}-0.0516 \\
(0.0797)\end{array}$ & $\begin{array}{l}0.0287^{* *} \\
(0.0133)\end{array}$ & $\begin{array}{c}0.0817 * * * \\
(0.0073)\end{array}$ & $\begin{array}{c}0.0420 \\
(0.0309)\end{array}$ & $\begin{array}{c}0.0992 * * * \\
(0.0131)\end{array}$ & $\begin{array}{c}0.0318 * * * \\
(0.0085)\end{array}$ \\
\hline $\operatorname{lnCR}_{\mathrm{i}, \mathrm{t}-2}{ }^{*}$ qualitysd $\mathrm{k}_{\mathrm{kt}}$ & $\begin{array}{c}0.0295 * * * \\
(0.0059)\end{array}$ & $\begin{array}{l}0.0002 * \\
(0.0001)\end{array}$ & $\begin{array}{c}0.0375 * * * \\
(0.0067)\end{array}$ & $\begin{array}{c}0.0266^{* * * *} \\
(0.0067)\end{array}$ & $\begin{array}{c}0.0149 \\
(0.0223)\end{array}$ & $\begin{array}{c}0.0345 * * * \\
(0.0131)\end{array}$ & $\begin{array}{c}0.0322 * * * \\
(0.0050)\end{array}$ & $\begin{array}{c}0.0106 \\
(0.0234)\end{array}$ & $\begin{array}{c}-0.0818 * * * \\
(0.0137)\end{array}$ & $\begin{array}{c}0.0579 * * * \\
(0.0065)\end{array}$ \\
\hline $\operatorname{lnGDPPC}_{\mathrm{it}}$ & $\begin{array}{c}0.0628^{* * * *} \\
(0.0043)\end{array}$ & $\begin{array}{c}0.1147^{* * *} \\
(0.0016)\end{array}$ & $\begin{array}{c}0.0906 * * * \\
(0.0061)\end{array}$ & $\begin{array}{c}0.0664 * * * \\
(0.0052)\end{array}$ & $\begin{array}{c}0.0343 \\
(0.0534)\end{array}$ & $\begin{array}{c}0.0672 * * * \\
(0.0071)\end{array}$ & $\begin{array}{c}0.0826 * * * \\
(0.0048)\end{array}$ & $\begin{array}{c}0.2532 * * * \\
(0.0420)\end{array}$ & $\begin{array}{c}0.0428 * * * \\
(0.0098)\end{array}$ & $\begin{array}{c}0.2252^{* * * *} \\
(0.0110)\end{array}$ \\
\hline $\operatorname{lnRD_{\text {it}}}$ & $\begin{array}{l}0.0259 * * * \\
(0.0050)\end{array}$ & $\begin{array}{l}0.0246^{* * * *} \\
(0.0019)\end{array}$ & $\begin{array}{l}0.0307 * * * \\
(0.0072)\end{array}$ & $\begin{array}{l}0.0204 * * * \\
(0.0059)\end{array}$ & $\begin{array}{l}-0.1110^{*} \\
(0.0624)\end{array}$ & $\begin{array}{c}0.0252 * * * \\
(0.0082)\end{array}$ & $\begin{array}{l}0.0238 * * * \\
(0.0056)\end{array}$ & $\begin{array}{c}-0.4481^{* * *} \\
(0.0583)\end{array}$ & $\begin{array}{c}-0.0433 * * * \\
(0.0082)\end{array}$ & $\begin{array}{l}0.0562 * * * \\
(0.0072)\end{array}$ \\
\hline $\operatorname{lnFDI} I_{\text {it }}$ & $\begin{array}{c}-0.0378 * * * \\
(0.0031)\end{array}$ & $\begin{array}{c}-0.0164 * * * \\
(0.0011)\end{array}$ & $\begin{array}{c}-0.0204^{* * * *} \\
(0.0044)\end{array}$ & $\begin{array}{c}-0.0276^{* * *} \\
(0.0037)\end{array}$ & $\begin{array}{c}0.0112 \\
(0.0422)\end{array}$ & $\begin{array}{c}-0.0423 * * * \\
(0.0051)\end{array}$ & $\begin{array}{c}-0.0162 * * * \\
(0.0034)\end{array}$ & $\begin{array}{c}-0.1054^{* * * *} \\
(0.0190)\end{array}$ & $\begin{array}{c}0.0009 \\
(0.0076)\end{array}$ & $\begin{array}{c}-0.0550 * * * \\
(0.0034)\end{array}$ \\
\hline Constant $_{\text {it }}$ & $\begin{array}{c}-1.5759 * * * \\
(0.0412)\end{array}$ & $\begin{array}{c}-1.6538 * * * \\
(0.0157)\end{array}$ & $\begin{array}{c}-1.8387^{* * *} \\
(0.0588)\end{array}$ & $\begin{array}{c}-1.5975 * * * \\
(0.0503)\end{array}$ & $\begin{array}{c}-1.0838 * * \\
(0.5122)\end{array}$ & $\begin{array}{c}-1.4479 * * * \\
(0.0684)\end{array}$ & $\begin{array}{c}-1.8383^{* * *} \\
(0.0461)\end{array}$ & $\begin{array}{c}-2.7155^{* * * *} \\
(0.3520)\end{array}$ & $\begin{array}{c}-1.5104^{* * *} \\
(0.0851)\end{array}$ & $\begin{array}{c}-3.2928^{* * *} \\
(0.1131)\end{array}$ \\
\hline $\mathrm{FE}$ & YES & YES & YES & YES & YES & YES & YES & YES & YES & YES \\
\hline Observations & 123,452 & 941,039 & 61,900 & 82,136 & 1,013 & 48,689 & 94,393 & 4,350 & 40,247 & 71,392 \\
\hline $\mathrm{R}$-squared & 0.2058 & 0.2746 & 0.2230 & 0.2198 & 0.1544 & 0.1981 & 0.2299 & 0.7007 & 0.2556 & 0.2779 \\
\hline
\end{tabular}

Notes: Standard errors are in parentheses and are robust to clustering. *, ** and *** indicates significance at the 10,5 and 1 percent level, respectively.

and credence goods and they have more serious problems with asymmetric information, we expect that the impact of country reputation on agricultural products is greater than that on non-agricultural products. We estimate equation (1) by using the data for non-agricultural products to certify the impacts of country reputation on the export quality of non-agricultural products and to identify the difference between the two categories of products. Columns (1) and (2) in Table 3 show the results. The coefficient of $\ln C R_{i t}$ in column (2) is significantly positive, which means that country reputation also has a positive impact on non-agricultural products. 
Furthermore, consistent with our expectations, the coefficient of $\ln C R_{i t}$ for non-agricultural products is smaller than that for agricultural products, which suggests a smaller impact of country reputation on export quality for non-agricultural goods than for agricultural goods.

\section{Capital vs. Intermediate vs. Consumption products}

We argue that country reputation may have heterogeneous impacts on the products of different end-use categories. There are three categories in the System of National Accounts (SNA): (1) capital goods, (2) intermediate goods, and (3) consumption goods. Consumption goods are products that are bought for consumption by the final consumer, are the end result of production and manufacturing and are what a consumer will see on store shelves. Intermediate goods are goods used as inputs in the production of other goods. The capital goods of the agri-sector are mainly live animals. Compared with consumption goods, capital goods require more investment and longer terms to improve quality. We assume that the producers may be less motivated to improve the export quality of capital goods and the country reputation may have heterogeneous impacts on different end-use goods.

Broad Economic Categories (BEC) provides a classification of goods by end-use category. We match SITC codes with BEC codes and classify our data set into three subsamples: intermediate goods, consumption goods and capital goods. Columns (3) - (5) of Table 3 display the results. The coefficient of country reputation is positive and significant for intermediate and consumption goods and insignificant for capital goods, which is consistent with our conjecture.

\section{Primary vs. processed products}

We examine to what extent the impacts of country reputation on export quality vary when moving from primary to processed products. Primary goods are those that characteristically are products of primary sectors of the economy-, i.e., farming, forestry, fishing, and the extractive industries. Since the value transformation of primary goods has made only a minor contribution, the producers may also be less motivated to improve their export quality.

We classify the data into two categories based on broad economic categories: primary goods and processed goods. The results are listed in columns (6) and (7). We can find that country reputation has a positive impact on the export quality of both primary goods and processed goods. However, the coefficient of country reputation in column (7) is significant at the $1 \%$ level while that in column (6) is significant at the 5\% level, which indicates that export quality of processed goods is more affected by country reputation than that of primary goods.

\section{Export countries with different income levels}

There is considerable heterogeneity across exported countries with respect to income levels. In this section, we test whether country reputation exerts heterogeneous effects on goods when they are exported by countries with different income levels. As noted in the existing literature on export quality, competition in highincome countries has switched from price-based to quality-based, while competition in low-income countries is still price-based (Hallak and Schott, 2011; Flach, 2016; Flach and Janeba, 2017). Therefore, they have different attention points on goods, and the effects of country reputation on export quality may exhibit country differences.

To support this hypothesis, we re-estimate equation (1) on three subsamples: low-income countries, middleincome countries and high-income countries ${ }^{4}$. Columns (8) - (10) of Table 3 indicate that country reputation has significant and positive impacts on quality improvements when goods are exported by middle- and highincome countries, while it has no significant impact on quality improvement when goods are exported by lowincome countries. This may be because the competitive price is still the most important component that allows producers to be successful in low-income countries and they may lack advanced technology to improve export quality.

\section{Robustness Checks}

To check the validity of our main results, we carry out several robustness tests. All regressions are estimated using OLS.

In columns (1) - (3) of Table 4, we test whether the results hold true when using different definitions of country reputation. In our baseline equation, country reputation is defined as the export quality index lagged by two years. To avoid biased results caused by the improper selection of period, we define country reputation as the export quality index lagged by one year and three years. The results indicate that the country reputation has a positive and significant impact on export quality and this effect is increasing in the first three years. These long-lasting effects suggest that countries with bad quality reputations may be locked into exporting low-quality and low-cost goods.

In column (4), we re-estimate equation (1) using unit values to measure product quality, which is common in the international trade literature. We have discussed its disadvantage in the previous chapter. However, unit values also have the advantage that they are available at practically all levels of disaggregation, and the analysis may therefore be conducted for bilateral trade flows at any level of aggregation (Aiginger, 1997; Hallak, 2006). Unit values can be obtained by dividing the values of

\footnotetext{
4 The World Bank has used an income classification to group countries for analytical purposes for many years. It divides countries into four groups: low income, lower middle income, upper middle income, and high income, by using gross national income (GNI) per capita valued annually in US dollars using a three-year average exchange rate. Here we use the income classification published in 2011. In addition, we grouped countries classified by the World Bank as lower middle income and upper middle income as middle-income countries.
} 
Table 4. Robustness checks

\begin{tabular}{|c|c|c|c|c|c|}
\hline VARIABLES & $\begin{array}{c}(1) \\
\operatorname{lag} 1\end{array}$ & $\begin{array}{c}(2) \\
\text { lag2 }\end{array}$ & $\begin{array}{c}(3) \\
\operatorname{lag} 3\end{array}$ & $\begin{array}{c}(4) \\
\text { price }\end{array}$ & $\begin{array}{c}\text { (5) } \\
\text { outliers }\end{array}$ \\
\hline \multirow[t]{2}{*}{$\operatorname{lnCR}_{\mathrm{i}, \mathrm{t}-2}$} & $0.0534^{* * *}$ & $0.0665 * * *$ & $0.0804^{* * *}$ & $0.0359 * * *$ & $0.0821^{* * *}$ \\
\hline & $(0.0075)$ & $(0.0069)$ & $(0.0079)$ & $(0.0022)$ & $(0.0073)$ \\
\hline \multirow{2}{*}{$\operatorname{lnCR}_{\mathrm{i}, \mathrm{t}-2} \mathrm{qualitysd}_{\mathrm{it}}$} & $0.0244 * * *$ & $0.0295 * * *$ & $0.0167^{* *}$ & $0.0283 * * *$ & $0.0394 * * *$ \\
\hline & $(0.0076)$ & $(0.0059)$ & $(0.0074)$ & $(0.0026)$ & $(0.0073)$ \\
\hline \multirow[t]{2}{*}{$\operatorname{lnGDPPC}{ }_{i t}$} & $0.0692 * * *$ & $0.0628 * * *$ & $0.0649 * * *$ & $0.0784 * * *$ & $0.0623^{* * *}$ \\
\hline & $(0.0042)$ & $(0.0043)$ & $(0.0046)$ & $(0.0012)$ & $(0.0043)$ \\
\hline \multirow[t]{2}{*}{$\operatorname{lnRD_{\text {it}}}$} & 0.0066 & $0.0259 * * *$ & $0.0274^{* * *}$ & $0.0404 * * *$ & $0.0265 * * *$ \\
\hline & $(0.0048)$ & $(0.0050)$ & $(0.0053)$ & $(0.0015)$ & $(0.0049)$ \\
\hline \multirow[t]{2}{*}{$\operatorname{lnFDI}{ }_{\mathrm{it}}$} & $-0.0436^{* * *}$ & $-0.0378 * * *$ & $-0.0393^{* * *}$ & $-0.0275^{* * *}$ & $-0.0386^{* * * *}$ \\
\hline & $(0.0031)$ & $(0.0031)$ & $(0.0034)$ & $(0.0010)$ & $(0.0031)$ \\
\hline \multirow[t]{2}{*}{ Constant } & $-1.6170 * * *$ & $-1.5759 * * *$ & $-1.5912^{* * *}$ & $-0.7108 * * *$ & $-1.5732^{* * * *}$ \\
\hline & $(0.0404)$ & $(0.0412)$ & $(0.0442)$ & $(0.0120)$ & $(0.0412)$ \\
\hline $\mathrm{FE}$ & YES & YES & YES & YES & YES \\
\hline Observations & 127,302 & 123,452 & 108,462 & 251,782 & 123,452 \\
\hline R-squared & 0.2018 & 0.2058 & 0.2046 & 0.3261 & 0.2065 \\
\hline
\end{tabular}

Notes: Standard errors are in parentheses and are robust to clustering. *, ** and *** indicates significance at the 10 , 5 and 1 percent level, respectively.

exported products by their physical quantities (UV = $\left.\frac{\text { value }_{i t}}{\text { quantity }_{\text {s. }}}\right)$. The results in column 4 are in line with the previous findings, indicating a significant positive impact of country reputation on export quality and suggesting that the unit value export prices indeed well capture export quality.

To investigate whether our main findings are driven by outlier observations, we delete observations that are above the upper quartile or below the lower quartile. The results in column (5) of Table 4 show that our main findings are robust to the exclusion of outlier observations.

These results of the above robustness checks are consistent with the baseline results, which indicate that country reputation significantly promotes the improvement of export quality.

\section{CONCLUSIONS}

The international trade of agricultural products has seen the growing importance of quality as a fundamental feature of products. Among the factors that determine export quality, country reputation has attracted the attention of scholars. Using the panel data in the period from 1996-2011 from 131 countries and 153 agricultural products, we investigate how country reputation affects the export quality of agricultural products. Strong evidence is found that country reputation has a positive and significant impact on export quality. Moreover, the positive impact of country reputation is more pronounced for highly differentiated products. These results remain stable and robust under different definitions of country reputation, alternative measurements of export quality and the exclusion of outlier observations. It is also shown that country reputation has heterogeneous effects on export quality when the sample is split based on different classifications.

This paper reviews and applies some recent studies in the literature to investigate the relationship between the country reputation and export quality of agricultural products in the international market. On the one hand, our work provides empirical research in the field of country reputation. On the other hand, our findings imply that high-reputation countries are likely to promote export quality while countries with bad quality reputations face the risk of falling into the "low-quality trap". Considering the long-term effects and the externalities of country reputation, it is necessary for lowreputation countries to adopt policy interventions to improve their country reputations.

\section{AUTHOR CONTRIBUTIONS}

Conceived and designed the methodology: Xuejun WANG, Koshi MAEDA and Dinghui HUAI. Analyzed the data: Dinghui HUAI and Xuejun WANG. Wrote the paper: Dinghui HUAI, Xuejun WANG and Koshi MAEDA.

\section{ACKNOWLEDGMENTS}

The study is supported by the Project of Philosophy and Social Science in Colleges and Universities of Jiangsu Province (2019SJA0044); the Fundamental Research Funds for the Central Universities of Nanjing Agricultural University (SKCX2019005); the Priority Academic Program Development of Jiangsu Higher Education Institutions (PAPD), and China Center for Food Security Studies, Nanjing Agricultural University. 


\section{REFERENCES}

Aiginger, K. 1997 The use of unit values to discriminate between price and quality competition. Cambridge J. Econ., 21(5): 571-592

Akerlof, G. A. 1970 The market for "lemons": quality uncertainty and the market mechanism. Q. J. Econ., 84(3): 488-500

Aw, B. Y., M. J. Roberts and D. Y. Xu 2008 R\&D investments, exporting, and the evolution of firm productivity. Am. Econ. Rev., 98(2): 451-456

Bilkey, W. J. and E. Nes 1982 Country-of-origin effects on product evaluations. J. Int. Bus. Stud., 13(1): 89-100

Cagé, J. and D. Rouzet 2015 Improving "national brands": Reputation for quality and export promotion strategies. J. Int. Econ., 95(2): 274-290

Chattalas, M., T. Kramer and H. Takada 2008 The impact of national stereotypes on the country of origin effect: A conceptual framework. Int. Mark. Rev., 25(1): 54-74

Chisik, R. 2003 Export industry policy and reputational comparative advantage. J. Int. Econ., 59(2): 423-451

Clarke, I., M. Owen and J. Ford 2000 Integrating country of origin into global marketing strategy: a review of US marketing statute. Int. Mark. Rev., 17(2): 114-126

Curzi, D., V. Raimondi and A. Olper 2015 Quality upgrading, competition and trade policy: Evidence from the agri-food sector. Eur. Rev. Agric. Econ., 42(2): 239-267

Curzi, D. and L. Pacca 2015 Price, quality and trade costs in the food sector. Food Policy, 55: 147-158

Damijan, J., M. Knell, B. Majcen and M. Rojec 2003 The role of FDI, R\&D accumulation and trade in transferring technology to transition countries: evidence from firm panel data for eight transition countries. Econ. Syst., 27: 189-204

Dasgupta, K. and J. Mondria 2018 Quality uncertainty and intermediation in international trade. Eur. Econ. Rev., 104: 68-91

Deng, L. and D. Liu 2018 Country reputation and North-South trade Based on Quality. World Economy Studies, 7: 108-122 (in Chinese)

Erdem, T., J. Swait, and A. Valenzuela 2006 Brands as signals: a cross-country validation study. J. Mark., 70(1): 34-49

Faruq, H. A. 2010 Impact of technology on export quality. J. Dev. Areas, 44: 167-185

Faruq, H. A. 2011 How insititutions affect export quality. Econ. Syst., 35(4): 586-606

Feenstra, R. C. and J. Romalis 2014 International prices and endogenous quality. Q. J. Econ., 129(2): 477-527

Flach, L. 2016 Quality upgrading and price heterogeneity: Evidence from Brazilian exporters. J. Int. Econ., 102: 282-290

Flach, L. and E. Janeba 2017 Income inequality and export prices across countries. Can. J. Econ., 50(1): 162-200

Flam, H. and E. Helpman 1987 Vertical product differentiation and North-South trade. Am. Econ. Rev., 77(5): 810-822

Hallak, J. C. 2006 Product quality and the direction of trade. J. Int. Econ., 68(1): 238-265

Hallak, J. C., P. K. Schott 2011 Estimating cross-country differences in product quality. Q. J. Econ., 126(1): 417-474
Hamzaoui, L. and D. Merunka 2006 The impact of country of design and country of manufacture on consumer perceptions of bi-national products' quality: an empirical model based on the concept of fit. Journal of Consumer Marketing, 23(3): 145155

Heneric, O., G. Licht and W. Sofka, Eds. 2006 Europe's automotive industry on the move: competitiveness in a changing world, 32 Springer Science and Business Media

Henn, C., C. Papageorgiou, J. M. Romero and N. Spatafora 2015 Export quality in advanced and developing economies: evidence from a new data set. WTO Work Pap., 2: 1-43

Hsiao, C. 2007 Panel data analysis-advantages and challenges. Test, 16(1): 1-22

Hummels, D. and P. J. Klenow 2005 The variety and quality of a nation's exports. Am. Econ. Rev., 95(3): 704-723

Iwamoto, M. and K. Nabeshima 2012 Can FDI promote export diversification and sophistication of host countries? dynamic panel system GMM analysis. Inst. Dev. Econ., 347: 2-8

Khan, H. and D. Bamber 2008 Country of origin effects, brand image, and social status in an emerging market. Hum. Factors Ergon. Manuf., 18(5): 580-588

Khandelwal, A. K. 2010 The long and short (of) quality ladders. Rev. Econ. Stud., 77(4): 1450-1476

Khandelwal, A. K., P. K. Schott and S. J. Wei 2013 Trade liberalization and embedded institutional reform: evidence from Chinese exporters. Am. Econ. Rev., 103(6): 2169-95

McQuade, T., S. W. Salant and J. Winfree 2016 Markets with untraceable goods of unknown quality: beyond the small-country case. J. Int. Econ., 100: 112-119

Melitz, M. J. 2003 The impact of trade on intra-industry reallocations and aggregate industry productivity. Econometrica, 71(6): 1695-1725

Minten, B., K. Murshid and T. Reardon 2013 Food quality changes and implications: evidence from the rice value chain of Bangladesh. World Dev., 42(1):100-113

Mohd, N. Y., M. N. Nasser and O. Mohamad 2007 Does image of country-of-origin matter to brand equity? J. Prod. Brand Manag., 16(1): 38-48

Nunn, N. 2007 Relationship-specificity, incomplete contracts, and the pattern of trade. J. Q. J. Econ., 122(2): 569-600

Olper, A., D. Curzi and L. Pacca 2014 Do food standards affect the quality of EU imports. Econ. Lett., 122(2): 233-237

Phillips, W. J., A. Asperin and K. Wolfe 2013 Investigating the effect of country image and subjective knowledge on attitudes and behaviors: US upper midwesterners' intentions to consume Korean Food and visit Korea. Int. J. Hosp. Manag., 32: 49-58

Sandu, S. and B. Ciocanel 2014 Impact of R\&D and innovation on high-tech export. Procedia Econ., 15: 80-90

Schott, P. K. 2004 Across-product versus within-product specialization in international trade. Q. J. Econ., 119(2): 647-678

Tirole, J. 1996 A theory of collective reputations (with applications to the persistence of corruption and to firm quality). Rev. Econ. Stud., 63(1): 1-22

Zhang, K. H. 2005 How does FDI affect a host country's export performance? The case of China. Conf. WTO, China Asia, 6 $25-26$ 
